\title{
Using Teacher Questions to Enhance EFL Students’ Critical Thinking Ability
}

\author{
Zhiwen Feng ${ }^{1, *}$ \\ ${ }^{1}$ School of Foreign Languages, Yunnan Normal University, Kunming, P.R. China \\ *Correspondence: School of Foreign Languages, Yunnan Normal University, Kunming, Yunnan, China. \\ E-mail: fengzhiwen1228@163.com
}

Received: July 23, 2013

doi:10.5430/jct.v2n2p147
Accepted: November 4, 2013 Online Published: November 14, 2013

URL: http://dx.doi.org/10.5430/jct.v2n2p147

\begin{abstract}
In this era of information and economic globalization, developing critical thinking skills in college students has been set as a primary goal and learning outcome in higher education. Teaching critical thinking, however, is a great challenge to most EFL teachers. This article, therefore, attempts to examine the nature and teachability of critical thinking, analyze and discuss the functions and types of teacher questions as well as Bloom's Taxonomy of Questions. Its primary purpose is to help EFL classroom instructors gain a deep understanding of teacher questions and get to know how to use higher order questioning to enhance EFL students' critical thinking ability.
\end{abstract}

Keywords: teacher questions; higher order questions; critical thinking; EFL teachers; EFL students

\section{Introduction}

Today higher education is facing great challenge of focusing its goal on the cultivation of talents with strong ability to solve real problems. Very often college students need to use their own brain to make insightful judgments. Developing critical thinking skills in college students has become an important issue (Yang, Newby \& Bill, 2005) and has been set as a primary goal in higher education (Tung \& Chang, 2009). "More recently, the Partnership for 21st Century Skills has identified critical thinking as one of several learning and innovation skills necessary to prepare students for post-secondary education and the workforce” (Lai, 2011, p.5). Accordingly, fostering EFL students' critical thinking, which is still a new area for many EFL teachers, is of great importance and significance.

Although students' critical thinking ability develops with age, some researchers contend that critical thinking can be taught or trained through formal instruction (King, 1995; Yang, Newby \& Bill, 2005; Khatib \& Nazari, 2012). In the past more than 20 years, quite a few instructional strategies have been practiced to develop college students' critical thinking. For example, classroom teachers manage to promote students' critical thinking through implementing cooperative learning (Cooper,1995), employing written and audiotaped dialogue journals (Khatib, Marefat \& Ahmadi, 2012), discussing the point of view in literature in EFL classes (Tung \& Chang, 2009; Khatib \& Nazari, 2012), using Socratic questioning (Yang, Newby \& Bill, 2005) and so on.

Based on the study of King (1995) and Taba (1966), the level of students' thinking is strongly influenced by the level of questions which are asked in class. Teachers' thoughtful questions play a crucial role in inducing students' higher level cognitive processes. Unfortunately, a majority of teachers' instructional time is spent asking students questions (Dillon, 1982), but not all teachers ask higher order questions to promote students' critical thinking. Most questions asked in a classroom context seem to be at the lower level of cognitive processes (Khan \& Inamullah, 2011). Traditionally, EFL teachers tend to emphasize covering text material over engaging students in independent thinking because they do not fully appreciate the role of questions in teaching content (Elder \& Paul, 1998). This article, therefore, based on contemporary literature, attempts to examine the nature and teachability of critical thinking, analyze and discuss the functions and types of teacher questions as well as Bloom's Taxonomy of Questions. Its primary purpose is to help EFL classroom instructors gain a deep understanding of teacher questions and get to know how to employ higher order questioning to foster EFL students' critical thinking ability. 


\section{The Nature of Critical Thinking}

Critical thinking, a hard-to-define concept, has philosophical and psychological roots (Lewis \& Smith, 1993). These two separate academic strands, through different approaches, define critical thinking with reflection of their own concerns. The third approach to critical thinking is within the field of education (Sternberg, 1986). According to the study of Paul and Elder (2001), critical thinking can be defined as a mode of thinking about any subject, content, or problem. With critical thinking college students can manage their thinking structures, employ intellectual criteria and finally improve their thinking quality. In the words of Lai (2011), "Critical thinking includes the component skills of analyzing arguments, making inferences using inductive or deductive reasoning, judging or evaluating, and making decisions or solving problems"(p.2). It is a kind of purposeful and self-regulatory judgment, ending in interpretation, analysis, evaluation and inference. And it involves conceptual and contextual basis of judgments (Facione \& Facione, 1996). In the eyes of Dewey (1933), learning to think is the central purpose of education.

For the term "Critical Thinking", its most recent definition was put forward in the book Asking the Right Questions: A guide to Critical Thinking by Browne and Keeley (2007). They defined "Critical Thinking" as "an awareness of a set of interrelated questions, an ability to pose and answer critical questions at appropriate time and a desire to actively use the critical questions"(p.2). Although the definition they provide has some similarities and is in the same trend with the precedent definitions, their emphasis has been placed on asking questions.

\section{The Teachability of Critical Thinking}

Critical thinking has been regarded as an essential outcome of education (Reed, 1998; Yang, Newby \& Robert, 2005) and it can be seen as an indispensible part of every school subject. With the rapid development of economic globalization, it is critical for EFL learners to strengthen their critical thinking skills. In order to achieve this goal, EFL learners need to receive formal instruction and training. Fortunately, "many critical thinking researchers maintain that critical thinking skills and abilities can be taught” (Lai, 2011, p.29).

Paul and Elder (2007) argue that students will be able to think critically when "they are consciously and deliberately thinking through some dimension of the logic of the discipline they are studying”(p.2). Similarly, Halpern (2003) claims that when critical thinking is explicitly taught by using various examples from academic disciplines, students will be able to learn to improve their thinking ability and habits. Therefore, although some authorities in higher education may not agree that college students should receive explicit instruction in how to think critically, it can be concluded that there must be a formal instruction on this subject area.

For the result of explicit instruction, Halpern (1998) has offered us good evidence from two teaching programs with an aim to strengthen students' critical thinking skills and ability. In one study, college students were taught general problem-solving skills and as a result their cognitive development was significant. In the other study, college students were purposely instructed in a specific type of problem-solving strategy and last they showed improvement in thinking skills. Kennedy et al. (1991) concluded that instructional interventions which aimed at promoting students' critical thinking ability have generally revealed positive results. Also, Ennis (1989) once described four approaches to critical thinking. The general approach is about direct and explicit instruction in critical thinking as a separate course. In other words, critical thinking can be taught as a separate and explicit part of school curriculum. Gelder (2005) appears to strongly support this general approach, advocating that students need to have "deliberate practice" in promoting critical thinking ability.

As for the improvement of EFL students' critical thinking ability, several instructional approaches have been attempted in recent years. In the study by Tung and Chang (2009), they incorporated a few strategies in course design to examine the efficacy of developing critical thinking through literature reading. One of their instructional strategies is guided in-class discussion with Socratic questioning skills. Similarly, Khatib and Nazari (2012) conducted a study to investigate the effect of teaching poetry on students' critical thinking ability. The results from data analysis indicate that using literature as a resource helps enhance students' critical thinking ability. In the study conducted by Khatib and Alizadeh (2012), using literary texts in reading comprehension classes to train students' critical thinking has proved to be an effective instructional strategy. Another study which has implications for the present one is that Yang, Newby and Bill (2005) used Socratic questioning to promote students' critical thinking skills. The author of this study also strongly holds a belief that incorporating higher-order questioning into EFL classes is an effective approach to strengthen students' critical thinking. The key to this instructional approach is that EFL teachers have to learn to "ask the right questions" (Browne \& Keeley, 2007). 


\section{Teacher Questions as One Way to Foster Students’ Critical Thinking}

\subsection{Functions of Teacher Questions}

In classroom instruction, questioning is regarded as one of the most popular teaching modes (Brualdi, 1998) and also it is one of the most frequently used instructional strategies. Zepeda (2009) states that questions can elicit students' responses which can range from simple recall of information to abstract processes of applying, synthesizing, and evaluating information. What is even more important is that the act of thinking is often driven by questions (Elder \& Paul, 1998). Therefore, EFL teachers can use questions to help students build understanding and think critically and creatively. Through the art of questioning, EFL teachers can unlock the hidden potentialities of college students and obtain teaching objectives more effectively.

Good thinking is prompted by good questions rather than correct answers. If students think through or rethink anything, they need to ask themselves thought-stimulating questions. The role of questions is to define tasks, convey problems and describe issues. In contrast, answers often signal a full stop in thought. According to the analysis of Elder and Paul (1998), only when an answer generates a further question does thought continue its life as such. Therefore, it's safe to say that only those students who have authentic questions can really think and learn. What's more, the quality of teacher questions determines the quality of students' critical thinking. The art of asking questions in class is one of the fundamental skills of good teaching (Khan \& Inamullah, 2011). Accordingly, few will deny that in order to teach well, teachers need to question well; and that good teachers ask good questions. Effective EFL teachers are certain to have a deep understanding of the types and cognitive levels of questions they ask everyday.

\subsection{Classifications of Teacher Questions}

Since questions have different functions, they can be divided into different categories. Judged by their syntax, questions may be classified into four kinds: Yes/no, either-or, tag, and wh- questions. According to the study of Celce-Murcia and Larsen-Freeman (1999), yes/no questions are primarily used to seek new information or clarify or confirm given or shared information. In contrast, wh-questions are used to elicit particular kinds of information. The nature of the information conditions the selection of the question word which begins with wh-. As for the tag questions and alternative questions, they are not used to seek information.

Seen from the instructional purposes, the questions an EFL teacher knows or might provide the answers for are called display or factual questions; and the questions to which the teacher doesn't know the answers are referential or open-ended. Kubota (1989) states that display questions require factual recall rather than higher level of thinking. In contrast, referential questions are used to challenge students to think and respond at higher levels of cognition, to stimulate creativity and to involve students by asking for their opinions. According to Nunn's analysis (1999), the only purpose of display questions is to prompt students to display knowledge of factual content already known to the teacher. Referential questions are questions to which the responses are not known by the teacher, directed towards the "real world" of the students. Badger (1992) argues that open-ended questions are used to examine students' understanding, reasoning ability and aptitude to apply knowledge in less traditional contexts. In general, open-ended questions require complex thinking, leading students to think analytically and critically.

The frequency of open-ended questions in classrooms is critical to teaching thinking. Nunan and Lamb (1996) pointed out that in classrooms of all kinds, display questions are by far the most common. For example, in a class they observed, the teacher asked twenty-two display questions, and only four are referential questions. According to the research findings of Blosser and Patricia (1995), about 60 percent of teacher questions require only recall of facts, 20 percent require students to think, and 20 percent are procedural in nature.

Another way is to classify teacher questions into convergent or divergent ones. Convergent questions, often used in textbooks, bring thoughts from different directions into a union or common conclusion. They call for a transfer of information in a predictable way. When students respond to a convergent question, they must know certain facts, be able to make connections and give an explanation. Unlike convergent questions, divergent questions are less predictable, having no right or wrong answers but encouraging the exploration of possibilities. Responding to divergent questions, students need an atmosphere in which they may explore ideas without pressure to give a "correct" answer. In answering this type of question, students might be asked to develop a plan to attack for a problem, propose solutions, create a product, or hypothesize from prior knowledge or experience. Due to the higher level of thinking this type of questions requires, it may take longer for students to construct responses. Similarly, Shaunessy (2000) strongly recommends several types of questions to prompt students' critical thinking. The first type is the divergent thinking question which probes beyond one-correct-answer question to delve more deeply into 
ideas. Additional types of questions such as synthesis and evaluation are provocative and hypothetical in nature. They are often used to encourage thoughtful reading, listening and viewing as well as asking students to seek new relationships.

In spite of other classifications, the above-mentioned types of teacher questions are quite dazzling in their variety. With the exception of question types such as tag, either-or, managerial, and structural questions, most other types of teacher questions fall within Bloom’s Taxonomy, which can promote higher forms of thinking in education.

\section{3 Bloom's Taxonomy of Teacher Questions}

In order to promote higher order thinking skills in education such as analyzing and evaluating, in 1956 Benjamin Bloom and associates created a Taxonomy of educational objectives. According to Bloom's Taxonomy, the questions teachers ask every day can be divided into six types: knowledge, comprehension, application, analysis, synthesis and evaluation. Seen from the functions of each type of questions, knowledge refers to remembering previously learned material. Comprehension demonstrates understanding of facts and ideas. Application is the use of principles, formulas, theories, concepts, or procedure in a new context to solve a problem. Analysis consists of breaking a piece of material or concepts into component parts and interpreting their interrelated relationship. Synthesis is to build a structure or pattern from diverse elements, putting parts together to form a new whole with emphasis on creating a new meaning or structure. Evaluation is to make reasoned judgments about the value of ideas or materials.

Bloom's Taxonomy is hierarchical, with "knowledge, comprehension and application" at the bottom and with "analysis, synthesis and evaluation" at the top. Since then Bloom's Taxonomy for information processing skills has been one of the most widely cited sources when educational practitioners assess higher order thinking skills. In the analysis of Kennedy et al. (1991), the three highest levels of skills (analysis, synthesis and evaluation) are often representative of critical thinking. Similarly, Hopper (2009) advocates that the last three types of questions employ higher order thinking skills. More specifically speaking, Bloom's Taxonomy is stratified from lower to higher levels. Lower level questions refer to those at the knowledge, comprehension, and simple application levels of the taxonomy, while higher level questions are those requiring complex application skills such as analysis, synthesis and evaluation. This simple classification of questions is both useful and accessible for EFL teachers. When the teaching focus is on the development of students' critical thinking, higher level questions are employed in classroom teaching. Of course, this does not exclude the use of lower-level questions as well. In a single class period, effective teachers vary the levels of questions as needed. It is widely recognized that different types of teacher questions prompt different types of cognitive thinking processes, and that not all questions can achieve the purpose of teaching higher order thinking to students. Wilen (1991) points out that classroom teachers often spend much time asking lower level cognitive questions, which concentrate on memorizable and factual information. Brualdi (1998) also states that factual questions may limit students' thinking by not helping them gain a deep understanding of the subject matter. Brualdi further resolves that higher level cognitive questions may be defined as those requiring students to use higher order thinking or reasoning skills. Through using such thinking skills, students can learn factual knowledge and further employ such knowledge to solve problems.

Having a better understanding of the types of lower and higher level cognitive questions in the actual process of teaching thinking is vital and necessary for EFL teachers. However, knowing how to help students to grow in critical thinking ability is another issue. To best achieve the latter, EFL teachers need a solid repertoire of "how" questioning strategies, because teaching thinking is a great challenge to both new and experienced EFL teachers. The following are three general instructional strategies for incorporating higher order questioning into EFL classes.

\subsection{Instructional Strategies to Ask Students Questions}

Effective teachers frequent exploit the 'wait-time' technique skillfully. "Wait-time” refers to the amount of time which elapses between a teacher-initiated question and the next verbal action. Usually, "wait-time" is just three to five seconds. In the past more than twenty years, empirical studies have shown that when classroom instructors wait three to five seconds after initiating a question, the nature of the discourse in class changes in a positive way. More students answer questions and their answers are more accurate, more elaborate and more reasoned. In other words, the level of students' answers becomes cognitively higher. The study by Stahl (1994) indicates that information processing involves multiple cognitive tasks that take time. Students need more uninterrupted periods of time to process information, reflecting on what has been said, observed or done. Therefore, the application of "wait-time" technique is of great significance in the effective use of higher order questions. 
Effective EFL teachers make a continuous effort to increase their awareness of higher order questioning in classrooms. They seek to avoid falling into the habit of often asking lower level cognitive questions. Much research on the behaviors and patterns of teacher questioning indicates that a classroom teacher spends about 80 percent of a school day asking students questions (Brualdi, 1998). Unfortunately, 70 to 80 percent of the teacher questions just require factual recall (Savage, 1998). Moreover, about 80 percent of what students learn through factual questioning is forgotten very soon. In contrast, 80 to 85 percent of what students learn from higher level questions is retained. Consequently, it is important and significant for EFL teachers to ask students more higher level cognitive questions. Questions allowing only one correct answer do not encourage critical thinking (Savage, 1998).

The last strategy is that fostering students' higher order thinking requires a positive classroom environment. In order to strengthen students' critical thinking skills through the use of questioning, EFL teachers need to establish a safe, non-threatening, encouraging and mutually respectful environment in the classroom. When students feel no pressure to give their responses, their minds will work faster and their thinking will be conducted at a higher level. Shaunessy (2000) concludes that the learning environment is strongly influenced by classroom teachers' behavior during their use of questioning and that teacher-student relationships must be of a supportive and respectful nature. Therefore, EFL teachers need to make great efforts to create a classroom environment that is conducive to developing students' critical thinking.

\section{Conclusions}

Developing higher critical thinking ability in college students has been regarded as an essential outcome of higher education. Teaching EFL students to think critically is naturally part of classroom teaching. In order to achieve this purpose, EFL classroom teachers should be experts at asking good questions and using appropriate strategies. Among all types of questions, asking higher order questions is imperative to the development of EFL students' critical thinking ability. To some extent, the questions teachers ask determine the direction in which their students' thinking goes. Only when students' thinking goes somewhere do students learn anything of value. Higher order questioning can drive students' thought below the surface of things, forcing them to deal with complexity. In order to achieve effectiveness in higher order questioning, EFL teachers need to know how to exploit good questioning strategies. Wigle (1999) points out that a questioning strategy may involve all students in the learning process; encourage all students to make an effort to prepare a response; allow adequate wait-time for cognitive processing; and facilitate opportunities for EFL students to engage in higher level thinking. Accordingly, skillful use of wait-time and creating a safe, respectful and encouraging thinking environment are integral to fostering higher order thinking in students. Teaching critical thinking is a great challenge, but it deserves commitment of the highest degree. If EFL students can strengthen their critical thinking skills at school today, they will become a qualified citizen tomorrow to solve any tough problems.

\section{References}

Badger, E., \& Thomas, B. (1992). Open-ended questions in reading. ERIC ED 355253.

Bloom, B. S. (1956). Taxonomy of educational objectives. Boston, MA: Allyn \& Bacon.

Blosser, B., \& Patricia, E. (1995). How to ask the right questions. Arlington, VA: Science Teachers Association.

Browne, M. N., \& Keeley, S. M. (2007). Asking the right questions: A guide to critical thinking. Upper Saddle River, NJ: Prentice Hall.

Brualdi, A. C. (1998). Classroom questions. ERIC ED 422407.

Celce-Murcia, M., \& Larsen-Freeman, D. (1999). The grammar book: An ESL/EFL teacher course. Heile \& Heile Publishers.

Cooper, J. L. (1995). Cooperative learning and critical thinking. Teaching of Psychology, 22(1), 7-8. http://dx.doi.org/10.1207/s15328023top2201_2

Dewey, J. (1933). How we think: A restatement of the relation of reflective thinking to the educational process. Lexington, MA: D.C. Heath.

Dillon, J. T. (1982). The multi-disciplinary study of questioning. Journal of Educational Psychology, 74(2), 147-165. http://dx.doi.org/10.1037/0022-0663.74.2.147

Elder, L., \& Paul, R. W. (1998). The role of Socratic questioning in thinking, teaching and learning. The Clearing 
House, 71(5), 297-301. http://dx.doi.org/10.1080/00098659809602729

Ennis, R. H. (1989). Critical thinking and subject specificity: Clarification and needed research. Educational Researcher, 18(3), 4-10. http://dx.doi.org/10.3102/0013189X018003004

Facione, N. C., \& Facione, P. A. (1996). Externalizing the critical thinking in knowledge development and critical judgment. Nursing Outlook, 44(3), 129-136. http://dx.doi.org/10.1016/S0029-6554(06)80005-9

Gelder, T.V. (2005). Teaching critical thinking: Some lessons from cognitive science. College Teaching, 53(1), 41-48. http://dx.doi.org/10.3200/CTCH.53.1.41-48

Halpern, D. F. (1998). Teaching critical thinking for transfer across domains: Dispositions, skills, structure training, and metacognitive monitoring. American Psychologist, 53(4), 449-455. http://dx.doi.org/10.1037/0003-066X.53.4.449

Halpern, D. F. (2003). Thought and knowledge: An introduction to critical thinking (4th ed.). Mahwah, New Jersey: Lawrence Erlbaum Associates.

Hopper, C. H. (2009). Practicing college learning strategies ( $5^{\text {th }}$ Ed). Cengage Learning, Inc.

Kennedy, M., Fisher, M. B., \& Ennis, R. H. (1991). Critical thinking: Literature review and needed research. In L. Idol \& B.F. Jones (Eds.), Educational values and cognitive instruction: Implications for reform (pp. 11-40). Hillsdale, New Jersey: Lawrence Erlbaum \& Associates.

Khan, W. B., \& Inamullah, H. M. (2011). A study of lower-order and higher-order questions at secondary level. Asian Social Science, 7(9), 149-157. http://dx.doi.org/10.5539/ass.v7n9p149

Khatib, M., \& Alizadeh, I. (2012). Critical thinking skills through literary and non-literary texts in English classes. International Journal of Linguistics, 4(4), 563-580. http://dx.doi.org/10.5296/ijl.v4i4.2928

Khatib, M., \& Nazari, O. (2012). The effect of literature on enhancing critical thinking. Journal of Comparative Literature and Culture, 1(2), 29-33.

Khatib, M., Marefat, F., \& Ahmadi, M. (2012). Enhancing critical thinking abilities in EFL classrooms: Through written and audiotaped dialogue journals. Humanity \& Social Sciences Journal, 7(1), 33-45.

King, A. (1995). Designing the instructional process to enhance critical thinking across the curriculum. Teaching of Psychology, 22(1), 13-17. http://dx.doi.org/10.1207/s15328023top2201_5

Kubota, M. (1989). Question-answering behaviors in ESL and EFL classrooms: Similarities and differences. ERIC ED 313913.

Lai, E. R. (2011). Critical thinking: A literature review. Retrieved July 30, 2013 from http://www.pearsonassessments.com/hai/images/tmrs/criticalthinkingreviewfinal.pdf

Lewis, A., \& Smith, D. (1993). Defining higher order thinking. Theory into Practice, 32(3), 131-137. http://dx.doi.org/10.1080/00405849309543588

Nunan, D., \& Lamb, C. (1996). The self-directed teacher. Cambridge: Cambridge University Press.

Nunn, R. (1999). The purposes of language teachers' questions. IRAL, 37(1), 23-42. http://dx.doi.org/10.1515/iral.1999.37.1.23

Paul, R., \& Elder, L. (2001). The miniature guide to critical thinking: Concept and tools. Dillon Beach, CA: The Foundation for Critical Thinking.

Paul, R., \& Elder, L. (2007). Consequential validity using assessment to drive instruction. CA: The Foundation for CT.

Reed. J. H. (1998). Effect of a model for critical thinking on student achievement in primary source document analysis and interpretation, argumentative reasoning, critical thinking dispositions, and history content in a community college history course. Unpublished doctoral dissertation. University of South Florid, USA.

Savage, L. B. (1998). Eliciting critical thinking skills through questioning. The Clearing House, 71(5), 291-293. http://dx.doi.org/10.1080/00098659809602727

Shaunessy, E. (2000). Questioning techniques in the gifted classroom. Gifted Child Today, 23(5), 14-21.

Stahl, R. J. (1994). Using ‘Think-Time' and 'Wait-Time’ skillfully in the classroom. ERIC ED 370885.

Sternberg, R. J. (1986). Critical thinking: Its nature, measurement, and improvement. Retrieved July 31, 2013 from 
http://eric.ed.gov/PDFS/ED272882.pdf

Taba, H. (1966). Teaching strategies and cognitive functioning in elementary school children. Cooperative Research Project, No. 2404. San Francisco: San Francisco State College.

Tung, C.A., \& Chang, S. Y. (2009). Developing critical thinking through literature reading. Journal of Humanities and Social Sciences, 19, 287-317.

Wigle, S. E. (1999). High quality questioning. The Education Digest, 65(4), 62-63.

Wilen, W. (1991). Questions, question techniques, and effective teaching. Washington, D.C.: National Education Association $\mathrm{f}$ the United States.

Yang, Y. C., Newby, T. J., \& Robert, L. B. (2005). Using Socratic questioning to promote critical thinking skills through asynchronous discussion forums in distance learning environments. The American Journal of Distance Education, 19(3), 163-181.

Yang, Y. T. C., Newby, T. J., \& Bill, R. L. (2005) Using Socratic questioning to promote critical thinking skills through asynchronous discussion forums in distance learning environments. The American Journal of Distance Education, 19(3), 163-181.

Zepeda, S. J. (2009). The instructional leader's guide to informal classroom observations. Larchmont, NY: Eye on Education, Inc. 